INFORMASI: Kajian Ilmu Komunikasi - ISSN (p) o126-0650; ISSN (e) 2502-3837

Vol. 48, No. 1 (2018), pp.33-48. doi: http://dx.doi.org/10.21831/informasi.v48i1. 19741

\title{
AN INITIAL EXPLORATION ON TERRORISM ISSUES IN MALAYSIA AND INDONESIA: THE CASE OF THE WALL STREET JOURNAL
}

\author{
Fauziah Hassan $^{1}$ \\ fauziah.hassan@usim.edu.my \\ Sofia Hayati Yusoff ${ }^{1}$ \\ sofia@usim.edu.my \\ ${ }^{1}$ Departemen of Communication Universiti Sains Islam Malaysia \\ Siti Zobidah Omar ${ }^{2}$ \\ zobidah@upm.edu.my \\ ${ }^{2}$ Departemen of Communication Universiti Putra Malaysia
}

\begin{abstract}
The symbiotic relationship between Islam and media is inevitable. The frequent of media coverage about Islam has been researched by many especially since the remarkable incident of September 11 in 2001. From that moment, Islam has been viewed and labelled as negative by the Western media specifically to the Muslims living in America and those in the Middle East countries. This phenomenon has been contagious to the Muslims in Southeast Asian countries such as Malaysia and Indonesia as these two countries are believed to have a connection with recent terrorist groups such as Islamic State of Iraq and the Levant (ISIL) and Islamic State in Iraq and Syria (ISIS). Therefore, this study was conducted to see the frequent coverage specifically on terrorism issues as reported by the Wall Street Journal (WSJ) and to explore the news themes that emerged in the news reporting. To realize this study, the researchers applied both quantitative and qualitative analysis to analyse the online news articles found in WSJ from year 2012 until 2013. The qualitative software was used in this study namely QSR Nvivo 11 to help and assist the researchers to store, manage and codify the news and also the quantitative software which is SPSS to calculate the frequencies of the reporting. The findings revealed that WSJ reported news related to terrorism in Malaysia and Indonesia frequently but it seems that Indonesia received higher percentage compared to Malaysia. In terms of news themes, the results found four major themes that are very much related to terrorism issues such as terrorist attacks, suspected as terrorist and robbery from both issues happened in Malaysia and Indonesia.
\end{abstract}

Keywords: Media and Terrorism, Terrorism News Reporting, News Themes on Terrorism Issues, Terrorism in Southeast Asian Countries. 


\section{INTRODUCTION}

Media misrepresentations of Muslims in Western countries, including Australia, Canada, the USA, the UK and Europe, has fuelled a lot of arguments and misunderstandingtowards Islamand Muslims (Rane \& Ewart, 2012) as the relations between Islam and the West have been depicted in many scholarly articles, research studies and media reports. In addition, the focus of Islam and Muslims has made the terms "Islam" and "Muslims" become important to the news media, subsequently, misrepresent the image of Islam (Kabir \& Bourke, 2012). According to Isyaku Hassan, Mohd N. L. Azmi and Usman Abu Bakar (2017), media has special interest towards Islam and terrorism since the terrible aftermath of $9 / 11$ and it has been supported previously by Ahmad (2006) who claimed that Islam and terrorism issues became inseparable in the media reporting. However, Hashim (2009) argued that the September 11 attacks were not actually a starting point that has made Islam being associated with terrorism but it has actually triggered the long hatred against Islam and Muslims by western society as Noor Mayudia et al. (2010) revealed that incident in Islamic countries such as Afghanistan and Iraq has been successfully manipulated in the media by giving negative stereotypes to Islam and Muslims. Consequently, previous study has shown that the rise in Islamophobia has led to negative portrayals on Muslims in Western media which is believed to be highly triggered after the September 11 attacks in 2001 (Allen, 2014; Alshammari, 2013; Funk \& Abdul Aziz, 2004). The incident of September 11 attacks has worsened the image of Islam and Muslims globally and finally made Islam grows with terrorism connotation.

The impact of issues related to Islam and terrorism not only affects Middle East countries, but Perrault (2014) indicates that it also affects other Muslim-majority countries but the research on this matter were found very little. Therefore, this article specifically aims to study on how Western media portrayed issues on terrorism in Malaysia and Indonesia which has a majority Muslim citizens stuck with the impact of world issues which are Islam and terrorism. The study focused on Malaysia and Indonesia is due to many scholarly works previously discussed on how news reporting on terrorism in Malaysia and Indonesia has been reported. For example, issues related to terrorism have widely reported in the mass media and this has been proved by Isma Adila (2011) who said that the terrorism issues especially in Indonesia has become a phenomenon and main topic highlighted in Indonesian media. This is because, terrorism has always related to conflict, bombing, terror threat and they have high news value and it is easy to attract the audience's attention (Isma Adila, 2011). Meanwhile, in Malaysia, there is a study by Dafrizal, Faridah, Chang and Fuziah (2013) shows the trend of news reporting on terrorism issues in Malaysia and Indonesia. Their study of four domestic newspapers - Utusan Melayu and New Straits Times (Malaysia) and Republika and Jakarta Post (Indonesia) - shows that the tone of the news on terrorism was prone to be negative (45.2\%, 114 news items) compared with (11.1\%, 28 news items) having a neutral tone.

Therefore, in this article, the researchers used framing theory as coined by Entman (1993) where the framing concept can determine what become a media agenda for the public's eye. In media, it has a perception related to matters which can attract the public attention. So, what is important to public or what has become the media agenda will eventually become the important issues among public. In this study, the researchers have narrowed down the scope of research by examining the contemporary trends in representing Islam and Muslims, specifically in Malaysia and Indonesia. Generally, the main aim of this study is to provide empirical evidence to shed light on the projected themes about Islam and Muslims in response to any significant events that happened in Malaysia and Indonesia. By using a purposive sampling, the Wall Street Journal (WSJ) from the US was selected based on the popularity and readership. Relevant news articles related to issues on terrorism in Malaysia and 
Indonesia were collected by using internetbased search from year 2012-2013. Thus, the researchers investigated the frequency of the reporting issues related to terrorism and finally looked into the themes that emerged in the news reporting within three consecutive years (2012-2013).

\section{NEWS REPORTING ON TERRORISM IN MALAYSIA AND INDONESIA}

More than 15 years ago, the tragedy of September 11, 2001, followed by the Bali bombing on 12 October 2002 have made the US perceives Southeast Asia as the second front in the worldwide battle against terrorism. The governments of Southeast Asian nations including the Philippines, Malaysia, Indonesia, Thailand and Cambodia also have been forced to join the US in the so-called antiterrorist coalition (Houben, 2003). As a result, these tragedies, to a certain extent shaped the news reporting on terrorism. Surprisingly, Islam in Indonesia has gained more attention from the media. In particular, issues concerning radical Islam, i.e., the aftermath of September 11 and the Bali bombing tragedy on 12 October 2002 (Eliraz, 2004). Furthermore, issues such as riots, apostasy, terrorism, anti-Islam movements, military intervention etc. were also portrayed frequently by the Indonesian media (Ghoshal, 2010). On a different note, The Economist reported in June 9, 2012 said that the Indonesian President was accused of being lenient in religious matters due to a planned concert by Lady Gaga, an American pop star. The Lady Gaga issue became international news when Islamic hardliners, the Islamic Defenders Front (FPI), forced her to cancel the concert.

Most recent, Tempo magazine in January 2016 reported that issues bombing in Thamrin, Jakarta has received coverage from Indonesian media and also international media this is because the bombing issues in Thamrin happened right after a month bombing in Paris. On theterror that happened in Thamrin has the similarity of the model of the attacks that took place in Paris and the group who conducted a raid allegedly from the ISIS terrorist group. Most importantly Luqman Rimadi (2016) stated that the location of Thamrin bombing was at the area of business centre, shopping mall and nearby the President Palace. The Thamrin bombing was surprised to many people because of the terrorist acts in Thamrin was new and it was not involved the suicide bomber but also the contact of the weapons committed by the terrorists and the police that took place in public areas.

According to Wicaksono (2017), due to this issue, journalists in two Indonesia magazines; Tempo and Gatra carry the coverage in different ways such as in terms of titles leads, news sources and photos. The value of the news in the Thamrin bomb was so powerful and it became a major reporting for Tempo and Gatra in two special editions. For example, Tempo reported the Thamrin bombing by directing the readers towards the suspect of terror through the headline of the news. Apart from that, Tempo magazine also explained the bomb events in chronological order. Unlike Tempo magazine, Gatra focused on the awakening about the terror and has increased radical and de-radicalization programs are being conducted on when in prison has failed and did not run well until it led to the bomb terror in Thamrin happened. In the context of this article, the researchers would like to see on how WSJ reported on issues related to terrorism in Malaysia and Indonesia in which contains different style of reporting based on the framing method analysis.

On the other hand, Kumala Citra (2016) also analysed bombing issues happened in the area of Sarinah, Jakarta. According to the report, the bomb blast happened on January 14, 2016 at the intersection area of Sarinah. This is the first bomb happened since bombing in Jakarta in 2009. Due to this incident, media has brought a lot of news related to the Sarinah bombing case. Kumala Citra (2016) analysed five articles from Kompas.com and Merdeka.com. She analysed all news collected and related to this issue based on three main aspects which are; lead 
of the story, news sources and news structure. Her analysis showed that all news used strict lead in order to explain that particular issue and it was relevant to describe the issue. Other than that, Kompas.com and Merdeka. com also used variety of news sources such as police, witnesses and society as to strengthen the news content. However, some of the news structure was completed but, there were some news did not explain deeply how the situation was before the bombing happened. Kumala claimed that journalists should provide information what is the condition of the place before bombs happened.

In discussing the news on Islam and terrorism between Malaysia and Indonesia, Dafrizal et al. (2013) believed that the emotional proximity between these two countries in which having similar cultural background and have majority Muslims societies surely have their own perceptions on how media from these two countries reported news on Islam and terrorism. The significant differences between media in these two countries is because of different ideology of the media organization. For example, media in Malaysia is operated and monitored by the government (Faridah Ibrahim, 2003; Zaharom Nain, 2002) meanwhile, media control in Indonesia has been terminated and become more critical (Toeti Kakiailatu, 2007).

Dafrizal et al. (2013) mentioned that previous study done by Dafrizal \& Faridah (2010); Faridah Ibrahim (2008); Mahony (2010) and Nelson (2004, 2006) did mention that both media in Malaysia and Indonesia do cover news related to terrorism especially issues that involved Malays family. However, if we want to compare between Malaysia and Indonesia, Indonesia has massive reports related to terrorism due to the several incidents of Bali bombing, the JW Marriot and Ritz Carlton hotels bombing which received wide reporting in media Indonesia and also Malaysia.

With regards to describing terrorism news reporting in Malaysia and Indonesia, Dafrizal et al. (2013) has elaborated the news excerpt from Utusan Malaysia which reported, "serangan Hotel JW Marriot dan Ritz-Carlton pada 17 Julai lalu memberi tamparan yang hebat buat negara Indonesia" (Utusan Malaysia, 25 Julai 2009). Meanwhile, Jakarta post newspaper also reported by saying "Noordin M Top. The fugitive Malaysian terrorist claimed responsibility for the bombings at JW Marriott and RitzCarlton hotels in Jakarta on July 17" (Jakarta Post, July31, 2009). The similar issues reported between these two countries is because of the incident happened in Indonesia but the suspected terrorists involved were from Malaysia namely Dr Azhari Husin and Noordin Mat Top.

Looking at the results obtained from the study done by Dafrizal et al. (2013), both newspapers in Malaysia and Indonesia directed to the negative reporting when it comes to the issue on terrorism which at $45.2 \%$ and the headlines used for all news articles collected were also dominantly negative which at $46.4 \%$. These results showed that news on terrorism mostly directed to the negative reporting where the researchers believed that headline, news structure and the use of news sources became the biggest contributions and influenced to the formation of news directions.

In Malaysia, issues on religious conflict in Malaysia as Malaysia is inhabited by people of diverse races and religions and this encourages every individual to understand the racial harmony as to ensure the peace and prosperity of the nation. In addition, every religion has a very different belief and tradition amongst others which need to be respected (Saodah, 2017). However, in Malaysia, the issue related to religious conflict seems endless. The unsettled issues related to religious conflict is due to the political atmosphere of Muslims now in crisis which can weaken the strength and integrity of Islam. This situation gives the opportunity to express their dissatisfaction with the practice of Muslims who have long been hidden in their hearts such as riots, demonstrations, protests and etc.

Because of the frequent coverage and reports of these issues domestically, it is 
not surprising that these issues can attract the attention of Western media and that they finally pick up them as their stories. This has been confirmed by Mahony (2010), who argues that the report on terrorism, interethnic and interreligious issues by the local media, e.g, the Indonesian news agency, have subsequently provided equal opportunity for Western media to cover similar issues.

Therefore, the researchers found out that this article certainly revealed the different results between news reporting on Islam and terrorism between Malaysia and Indonesia. WSJ in its reporting will definitely reported news towards this issue but maybe different in terms of frequency and themes found.

\section{ISLAM AND MUSLIMS IN MALAYSIA AND INDONESIA}

The topic of Islam in Southeast Asia has long been marginalized in the fields of both Islamic studies and Southeast Asian studies. As Hefner and Horvatich (1997) wrote, "scholars from Western and Middle Eastern alike to place Southeast Asia at the intellectual periphery of the Islamic world" (pp. 8). This region has been observed as "peripheral" and has gained limited attention. In terms of the Muslim population, almost 9o\% of the more than 230 million population citizens of Indonesia are Muslim and 58\% of the citizens of Malaysia are Malays and therefore, they are Muslims too (Houben, 2003). This argument also based on previous study which indicated that Islam and Muslims have been commonly accepted as synonymous (Ridzuan Wu, 1990).

Pew Research Center (2015) reports that Muslims are the major religious group projected to increase faster than other religions between 2010 and 2050. In 2014, there were approximately 18 million Muslims in Malaysia (60.4\% of population) and 218.68 million (88\%) in Indonesia (Asia Muslim Population, 2014). According to the Population Reference Bureau, Islam is the fastest-growing religion in the world because of the pace of the demographic transition in the Muslim-majority countries relative to the rest of the world. Malaysia and Indonesia are two countries in Southeast Asia categorized among countries with more than 50\% Muslim population. Malaysia falls within the $50-69 \%$ band and Indonesia the $70-89 \%$ band (Population Reference Bureau, 2014). Based on this forecast, Muslims population will continue to soar in the near future.

The many Muslims in Indonesia belong to a diverse nation which consists of hundreds of different ethnic groups, religions, languages and also cultures. The majority of Indonesians are Muslims who practice moderate Islam, and Islam in Indonesia is substantially diverse in terms of influences, forms and practices (Mahony, 2010). In addition, WSJ reported that Indonesia can be categorized as a tolerant country where six religions: Islam, Protestantism, Catholicism, Hinduism, Buddhism and Confucianism can be practiced equally under the same law and with equal rights of worship (WSJ, 7 August 2013).

In Malaysia, Islam is the official religion as provided by the Federal Constitution. On the contrary, Islam is not an official religion in Indonesia even though Indonesia has an overall majority of Muslim population (Houben, 2003). The government of Indonesia pays close attention to the religious needs of the Muslim community but it has not transformed Indonesia into an Islamic state as this was strongly opposed by the late President Suharto and by the Indonesian armed forces (Desker, 2002). This research is innovative in studying a topic related to Islam and Muslims specifically in Malaysia and Indonesia. The different ideologies about the position of Islam between these two countries will make this study very interesting because, although both countries are dominated by a majority Muslims and consist of multiple races, cultures and religions, the Indonesian policy is seen to be more flexible and more open towards religious practices compared with that of Malaysia.

\section{Definition of terrorism}

The relation between media and 
terrorism is inevitable. In fact, there are several views about media and terrorism which have been discussed before. According to Mc Quail (1995), media provides way to the government to deal with terror issues. For example, media giving a negative label or name to the terrorist groups and be able to generate panic situations to frighten the terrorists through spreading the information. By definition, the word terrorism has been specifically defined in media since 1960 s in the labelling and framing some issues or events. Terrorism is becoming common in news coverage and sometimes becomes an exclusive genre both in televisions and newspapers (Mc Quail, 1995). Apart from that, Severin and Tankard (2001) categorize terrorism as one of the seven propaganda devices which is classified as 'name calling' that gives an idea and a bad name, used in rejecting or threatening without investigating based on given evidences. However, Laqueur (2002) added that the terrorism must be related with religious movements, political revolts as well as social uprisings. In 2003, Andrew Silke defined terrorism as the term used to show a violated act which is considered as violated and violent due to its nature which is against the norm and human's rights. Cassidy (2008) claims that the war on terrorism will have lasted for years, making it much longer than the American Civil War or World War II. Recently, Shafizan, Mazni Buyong \& Zeti Azreen (2014) described terrorism as the actions that intend to boost fear with regard to achieve their ideology and neglect safety of others. They continued saying that Western media have portrayed Muslim as terrorist through movies to gain influence from audiences.

\section{RESEARCH QUESTIONS}

This study examined the frequency of news coverage related to Islam and Muslims in Malaysia and Indonesia from the perspective of WSJ. Apart from that, the news theme is explored to make the study more wideranging. Based on the scenario discussed in the problem statement, this study addresses the following research questions:
1) In terms of quantity of coverage, how is news related to Islam and Muslims in Malaysia portrayed differently from news related to Islam and Muslims in Indonesia as reported in WSJ?

2) What are the themes related to terrorism in Malaysia and Indonesia had been reported by WSJ in year 2012-2013 period of time?

\section{SPECIFIC OBJECTIVES}

1) To determine the different frequencies of news coverage related to Islam and Muslims between Malaysia and Indonesia being reported by WSJ;

2) To explore the themes related to terrorism emerged in reporting issues related to Islam and Muslims in Malaysia and Indonesia within the chosen time frame selected for the study.

\section{METHOD}

In this study, both quantitative and qualitative methods were applied. Quantitative and qualitative styles of research differ in several ways but actually they are complementary to each other (Neuman, 1997). Creswell (2012) indicates that, to interpret the comprehensive result, the data from quantitative data collection and analysis can be followed up by qualitative data collection and analysis in order to enrich the discussion of the findings. Similarly, Miller and Daily (2013) mention that data from both can complement each other, whereby the qualitative data produces thorough meaning and in-depth data set in comparison to quantitative data. Therefore, the researcher sets out to incorporate both quantitative and qualitative methods in this research.

The quantitative and qualitative of content analysis were applied in order to organise this research. According to Sealeand Tonkiss (2012) this methodological approach focuses on several aspects such as words or categories, number of lines, amount of space and different themes while also focusing in the reproduction of underlying meanings. Therefore, in this study, the researchers 
analysed news articles on terrorism issues related to Islam and Muslims as reported by WSJ. The use of news articles as the main subject in this research is followed by Neuman (2014) who said that many social researchers use reports in newspapers as a data source to analyse the content of the articles and count key events by identifying words, meanings, pictures, symbols, ideas, themes. Hence, this study collected news articles related to this issue from 2012 until 2013 through subscribing to the news organisation. The selection of the related articles was based on several keywords such as "terrorism in Malaysia”, "terrorism in Indonesia”, Islam in Malaysia" and "Islam in Indonesia". A total of 23 news articles have been collected from WSJ within two years and all of them have been analysed with the use of QSR Nvivo 11 in which related to the theme of terrorism.

In this presentstudy, the researchers used online news articles. The rationale of using online news instead of the printed version is due to the difficulties of the researchers accessing print copy versions of international newspapers in Malaysia. Subscribing to this news organizations in order to get full access to their newspaper archives was an ideal alternative. Valid subscriptions to this news organizations may avoid any ethical issues of online data collection, as Merriam (2009) pointed out that the nature of content in online documents and artefacts is usually ephemeral and changeable.

The subscription to the news organization can ensure the reliability and trustworthiness of the online news. Therefore, the researchers purchased the full-text version of WSJ newspaper. It is important to know that WSJ newspaper is printed in four editions: Asia, Europe, India and the US. Therefore, to have a balance in collecting the sample, the researchers intentionally chose the US edition of WSJ and all the news articles for this study were gathered from the "Asia column".

\section{QUANTITATIVE CONTENT ANALYSIS}

According to Wimmer and Dominick
(2011), one of the advantages of using Quantitative Content Analysis is to explore the issues that exist in the online news reports. Therefore, this method is suitable to identify the frequency of the news reports that are related to Islam and Muslims in Malaysia and Indonesia as reported by WSJ as the researchers subscribed to this news portal. Apart from that, the determination of news focus either Malaysia or Indonesia is also developed through this method. The content analysis has been used widely among previous scholars and researchers to study the frequency of coverage of Islamic issues in the newspapers. For example, research done by Raqib and Adnan (2013) also used quantitative content analysis in order to analyse the frequency of the news reports related to the controversial religious problems in Malaysia from two mainstream newspapers in Malaysia. In particular, the researchers employed Quantitative Content Analysis by using a separate coding sheet for content analysis to examine the basic information or background of the news articles in the selected news report, such as date, year, headline, name of the newspaper, number of paragraphs, focus of the news.

Therefore, this phase only measured the frequency of news coverage on Islam and Muslims in Malaysia and Indonesia by WSJ and also the news focus. The researchers used Statistical Package for Social Sciences (SPSS) Version 22 to draw the descriptive findings as presented in the table below to describe the frequency distribution. The use of SPSS Version 22 helps the researchers to store and analyse the data and to present the report data in tables, charts and graphs (Macnamara, 2011).

\section{QUALITATIVE CONTENT ANALYSIS}

According to Ji Young Cho and Eun-Hee Lee (2014), the qualitative content analysis is chosen purposely to focus on the data analysis process. The qualitative content analysis applies an inductive approach (selecting the units of analysis, open coding, creating categories, data coding and revising 
categories) and a deductive approach (selecting the unit of analysis, deciding and defining categories derived from prior theory, coding data into the predetermined categories and revising categories). In this study the data analysis process involved the steps of open coding, axial coding and selective coding.

Many scholars, such as Neuman (2006) and Paton (2001) argue that in qualitative

Table 1: List of News Articles Examined

\begin{tabular}{|c|c|c|c|c|c|c|}
\hline No & Year & $\begin{array}{l}\text { News } \\
\text { Focus }\end{array}$ & Date & Headline & Paper & $\begin{array}{c}\text { No of } \\
\text { Paragraph }\end{array}$ \\
\hline 1 & \multirow[t]{4}{*}{2012} & \multirow[t]{8}{*}{ Malaysia } & 10 Feb 2012 & Saudi tweeter is Arrested in Malaysia & WSJ & 13 \\
\hline 2 & & & 10 Apr 2012 & New Protest Rally Planned in Malaysia & $W S J$ & 13 \\
\hline 3 & & & 28 Oct 2012 & Two Malaysians Are Arrested in Lebanon & WSJ & 20 \\
\hline 4 & & & 18 Dec 2012 & $\begin{array}{l}\text { Malaysia Takes In 4o Myanmar Shipwreck } \\
\text { Survivors }\end{array}$ & WSJ & 17 \\
\hline 5 & \multirow[t]{4}{*}{2013} & & 25 Jan 2013 & $\begin{array}{l}\text { Catholic Church's New Envoy to Malaysia } \\
\text { Wants Closer Ties With Muslims }\end{array}$ & WSJ & 16 \\
\hline 6 & & & 6 June 2013 & $\begin{array}{l}\text { Malaysia Fears Spillover From Myanmar } \\
\text { Violence After } 4 \text { Killed }\end{array}$ & WSJ & 18 \\
\hline 7 & & & 5 Oct 2013 & $\begin{array}{l}\text { Muslim Group Protests U.S. Secretary of } \\
\text { State's Malaysia Visit }\end{array}$ & WSJ & 7 \\
\hline 8 & & & 18 Nov 2013 & $\begin{array}{l}\text { Malaysia Seeks Philippine Help in } \\
\text { Tracking Kidnapped Tourist }\end{array}$ & WSJ & 10 \\
\hline 9 & \multirow[t]{9}{*}{2012} & \multirow[t]{15}{*}{ Indonesia } & $\begin{array}{l}23 \text { January } \\
2012\end{array}$ & Indonesian Detained for Facebook Post & WSJ & 10 \\
\hline 10 & & & 15 May 2012 & $\begin{array}{l}\text { Indonesia Blocks Gaga After Islamists } \\
\text { Protest }\end{array}$ & WSJ & 11 \\
\hline 11 & & & 28 May 2012 & Lady Gaga's Appeal Growing in Indonesia & WSJ & 9 \\
\hline 12 & & & 21 June 2012 & $\begin{array}{l}\text { Court Sentences Man to } 20 \text { Years in Bali } \\
\text { Bombing }\end{array}$ & WSJ & 16 \\
\hline 13 & & & 23 July 2012 & $\begin{array}{l}\text { Peterpan Star Released from Indonesian } \\
\text { Prison After Sex-Tape Scandal } \\
\end{array}$ & WSJ & 9 \\
\hline 14 & & & 16 July 2012 & $\begin{array}{l}\text { Shiite's Conviction Raises Concerns About } \\
\text { Intolerance }\end{array}$ & WSJ & 19 \\
\hline 15 & & & 23 Sept 2012 & Indonesia Arrests 1o Suspected Militants & WSJ & 13 \\
\hline 16 & & & 28 Oct 2012 & $\begin{array}{l}\text { Indonesia Arrests } 11 \text { in Suspected Terror } \\
\text { Plot }\end{array}$ & WSJ & 5 \\
\hline 17 & & & 31 Dec 2012 & $\begin{array}{l}\text { Indonesia Takes In 9 Myanmar Shipwreck } \\
\text { Survivors }\end{array}$ & WSJ & 16 \\
\hline 18 & \multirow[t]{6}{*}{2013} & & \begin{tabular}{|l}
5 January \\
2013
\end{tabular} & $\begin{array}{l}\text { Indonesia Police Kill Five Alleged } \\
\text { Terrorists }\end{array}$ & WSJ & 13 \\
\hline 19 & & & \begin{tabular}{|l|}
6 January \\
2013 \\
\end{tabular} & $\begin{array}{l}\text { Indonesian Authorities Fight A New } \\
\text { Terror Front }\end{array}$ & WSJ & 12 \\
\hline 20 & & & \begin{tabular}{|l|}
15 March \\
2013 \\
\end{tabular} & $\begin{array}{l}\text { Poli Police Kill } 3 \text { Suspected Militants In } \\
\text { Jakarta }\end{array}$ & WSJ & 14 \\
\hline 21 & & & 13 April 2013 & $\begin{array}{l}\text { Seven Police Hurt In Indonesia } \\
\text { Protest } \\
\end{array}$ & WSJ & 9 \\
\hline 22 & & & 8 May 2013 & $\begin{array}{l}\text { Indonesian Police Slay Suspected Bomb } \\
\text { Plotters }\end{array}$ & WSJ & 28 \\
\hline 23 & & & $\begin{array}{l}13 \\
\text { November } \\
2013\end{array}$ & $\begin{array}{l}\text { Indonesia Charges Alleged Bomb } \\
\text { Plotter With Terrorism }\end{array}$ & $W S J$ & 11 \\
\hline
\end{tabular}


analysis the researcher usually becomes the research instrument. The work of a researcher includes selecting newspapers, selecting news articles, coding the news articles and finally storing and managing them with a qualitative analysis software. However, in this study, the researchers have provided a set of forms that contain to determination of news theme.

\section{Open Coding Analysis}

In conducting this research, the qualitative analysis procedure has been applied which means theopen coding analysis and axial coding analysis. In the open coding analysis, the researchers developed the categorization of the news and basic themes of the news. From the analysis, there are 23 news themes were found under the theme of terrorism. This is including news related to bombing, riot, attack/terrorist attack, cybercrime, killing, suspected terrorist, white collar crime, immoral, kidnapped, link with terrorist and robbery.

\section{Axial Coding Analysis}

The objective to develop the axial coding analysis is to search for a connection or relationship among themes. This study found that 23 news reporting on terrorist or terrorism issues has been classified into two main-themes which are terrorist attacks and suspected as terrorist.

\section{FINDINGS}

This article examined WSJ representing the issue related to terrorism in Malaysia and Indonesia from two consecutive years (20122013). All news articles were subjected to both quantitative and qualitative content analysis through selected news articles with regard to determine the frequency and the themes of the news. To ensure the consistency of the news articles being selected, the technique of composite week sampling technique have been employed. This is to avoid having bias and focusing on the similar issue. Findings of the coverage shows that WSJ was prone to cover terrorism issues in Indonesia compared to Malaysia. The analysis of this articles were reflected to two main themes both happened in Malaysia and Indonesia which are; terrorist attacks and suspected as terrorist. The table below is the list of news articles that are related and has been used as a sample for this study.

\section{The Frequency of News Reporting Using Quantitative Content Analysis}

Table: 2: News Articles related to Islam and Muslims according to Year and News Focus in WSJ

\begin{tabular}{|c|c|c|c|}
\hline Newspaper & Year & News Focus & Total (\%) \\
\hline WSJ & 2012 & Malaysia & $4(30 \%)$ \\
& & Indonesia & $9(70 \%)$ \\
& & & \\
\cline { 2 - 4 } & Total & & $\mathbf{1 3}(\mathbf{1 0 0} \%)$ \\
\cline { 2 - 4 } & 2013 & Malaysia & $4(40 \%)$ \\
& & Indonesia & $6(60 \%)$ \\
& & & \\
\cline { 2 - 4 } & Total & & $\mathbf{1 0}(\mathbf{1 0 0} \%)$ \\
\hline Overall & & & $\mathbf{2 3}(\mathbf{1 0 0} \%)$ \\
\hline
\end{tabular}

As mentioned earlier, the selection of WSJ as the subject in this study was based on purposive sampling which several characteristics of the samples have been determined to meet the research objectives. In this case, the WSJ has been chosen to represent the leading mainstream newspaper in the US with regard to see the frequent reporting on Islam and Muslims in Malaysia and Indonesia in its specific column allocated in Asia.

Since this research studies news from a certain period, 2012-2013, the researchers has itemized the news samples according to year. As illustrated in Table 2, the majority of the news articles were published in WSJ $(\mathrm{N}=23)$. For WSJ, it isapparent from Tables that within the two-year period the greatest number of news articles collected was in $2012(\mathrm{~N}=13)$ with $(\mathrm{N}=10)$ news articles were collected respectively in 2013. The total number of news articles collected in two consecutive 
years seem uneven. However, the researchers agreed that the imbalance in the amount of news articles is one of the drawbacks when dealing with newspaper articles as the main data. According to Rose, Spinks and Canhoto (2015), potential weaknesses when conducting a content analysis approach lies in the process of sampling, process of coding and document availability.

Having presented the news articles according to year, the analysis continues to present the frequency of news articles according to news focus in Table 2 . Based on the above table, Indonesia has received more coverage in two years compared to Malaysia. The above table showed that Indonesia has 9 articles related to terrorism issues in 2012 and 6 news articles in 2013. If to compare with Malaysia, WSJ only produced 4 news articles related to terrorism in Malaysia in both years.

From the viewpoint of the researchers, the numbers of news collection from WSJ signalled that the US newspaper (WSJ) has given loads of coverage related to Islam and Muslims issues both in Malaysia and Indonesia. However, the researchers believed that the high attention given to Indonesia in this study was in line with the few terrorism issues in Indonesia that has attracted attention of international media indirectly.

\section{The News Themes of Reporting Using Qualitative Content Analysis}

From the open coding analysis, the researchers found news related to bombing, riot, attack/terrorist attack, cyber-crime, killing, suspected terrorist, white collar crime, immoral, kidnapped, link with terrorist and robbery. However, in this article, the researchers only analysed two major themes that related to terrorism which are; Attack/Terrorist Attacks and Suspected Terrorist. Through the analysis made, the researchers elaborated these two themes as provided below.

\section{Attack/Terrorist Attacks}

Past research has proved that the theme of Islam, violence or any theme related to terrorism must be included when researching issues surrounding Islam and Muslims. The researchers believed that the theme of Islam and violence would be a very popular theme emerging in any study relating to Islamic issues. However, in this present study, the researchers found that the theme of Islam and violence as reported in WSJ received very little coverage. This showed that WSJ did not put this theme uppermost when reporting the issues related to Islam and Muslims in Malaysia and Indonesia but still do the coverage pertaining Islam and Muslims apart from terrorism issues (Fauziah, 2017). In this analysis, however, several issues such as killing, bombing, attacking, public demonstrations etc. are among the examples of how issues related to Islam/Muslims have links to violence. To compare the coverage between Malaysia and Indonesia, it can be seen that Indonesia has more coverage relating to Islam and violence compared with Malaysia.

For example, on 28 October 2012, WSJ reported extensively on the issues relating to attacks and suspected terrorists. The news excerpt below reported that Indonesian police had arrested 11 suspected terrorists who planned to attack the US embassy in Jakarta. WSJ reported:

Indonesian police arrested 11 people suspected of planning terrorist attacks on targets across the country, including U.S. diplomatic missions, in the latest in a series of crackdowns on small suspected terrorist groups in the world's largest Muslim-majority nation (WSJ, October 28, 2012: Line 12)

The group was planning attacks on the U.S. embassy in Jakarta, the U.S. Consulate in Surabaya, and a building near the Australian Embassy in Jakarta that is also an office of the Indonesian arm of U.S. mining giant FreeportMcMoRan Copper \& Gold Inc._The terrorists were allegedly also targeting the Central Java headquarters of the 
Fauziah Hassan, Sofia Hayati Yusoff, dan Siti Zobidah Omar, An Initial Exploration on Terrorism Issues in Malaysia ...

police mobile brigade, police said (WSJ, October 28, 2012: Line 19)

In the news report, the Indonesian authorities confirmed that the planning of terrorist attacks as reported in 28 Octoberwas due to commemorate the tenth anniversary of the Bali attacks which occurred on 12 October 2002 and killed 202 people including foreign tourists. The police spokesman added that the suspected terrorists were known as a group named Haraqah Sunni for Indonesian Society, or Hasmi.

The other issue that appeared frequently under this sub-theme is about the conflicts between Buddhists and Muslims in Myanmar. Even though this issue is not related with terrorism in either in Malaysia or Indonesia, but this conflicts happened in Malaysia and Indonesia. This is indirectly worsened Malaysian and Indonesian citizens as it has increased the tension. In Malaysia, this issue has gained the attention of WSJ which reported on the issue of killing and protest. In a news report dated 6 June 2013 it was stated that eight people were killed after a fight between Muslim and Buddhist refugees from Myanmar. WSJ reported:

At least eight people were killed after Muslim and Buddhist refugees from Myanmar fought pitched battles at a detention camp in Indonesia in April, spurred on in part by violence between ethnic-Rohingya Muslims and Buddhists in western Myanmar that claimed over 160 lives last year and an outbreak of similar rioting in central Myanmar that killed at least 43 people in March (WSJ, June 6, 2013: Line 15)

The conflict has caused worry to the government of Malaysia as Malaysia is a close neighbour of Myanmar. It was reported by WSJ on 6 June 2013:

Malaysian authorities worry that ethnic and racial tensions in nearby Myanmar are spilling over into their country after a series of clashes between Myanmar nationals near Kuala Lumpur left at least four people dead (WSJ, June 6,
2013: Line 9)

On top of that, WSJ on 9 December 2013 reported that an Indonesian had been detained relating to the issue of bombing the Myanmar embassy in Jakarta. WSJ reported:

A 29-year-old Indonesian admitted
building a bomb intendedfor Myanmar's
embassy in Jakarta this year, the first
confession in what police call a plot
against Buddhists who have clashed with
Muslims in Myanmar (WSJ December
9, 2013: Line 12)

The above examples of news excerpts show that the most central issues discussed were about terrorism activities and also the conflicts between Muslims and Buddhists in Myanmar. To discuss the issue of Myanmar's conflict, the previous study has proved that even though Muslims living in Southeast Asia have been living peacefully with other nonMuslim communities the religious tensions which involve ethnic and racial tensions can also contribute to the violent conflicts such as in Myanmar (Fealy \& Hooker, 2006). From the researchers' point of view, the issue of Rohingya has contributed much to this conflict.

Based on the example of the excerpts above, the researchers found that the news related to attacks or terrorist attacks were found mainly in Indonesia. The terrorist groups have targeted several important places such as the US embassy in Jakarta, the US consulate in Surabaya, and a building near the Australian embassy in Jakarta that is also an office of the Indonesian arm of US, and also targeting the Central Java headquarters of the police mobile brigade. According to the website of Risk Management Solutions (2012), the Bali bomb attack in October 2002 was one of the world's deadliest terrorist attacks of the last decade. Historically, the attack by Indonesian suicide bombers killed 202 and injured 350 people from more than 22 countries. The attack was believed to have done jointly by Al-Qaeda and Jemaah Islamiyah (JI) to avenge the US-led coalition intervention in Afghanistan. 


\section{Suspected Terrorist}

WSJ reported that the government of Indonesia was afraid that groups might have been planning attacks targeting dignitaries who were on the resort island of Bali on 12 October to commemorate the tenth anniversary of the Bali bombing. On 22 July 2013, WSJ also reported on the issue of suspected terrorists. It quoted:

Indonesian police shot and killed two suspected terrorists with links to the country's most-wanted militant (WSJ, July 22, 2013: Line 11)

As stated in the news, the police officer said that all of them were believed to have been involved with Santoso, leader of the militant group Mujahidin Indonesia Timur. $\mathrm{Mr}$ Santoso is a former member of JI, the Southeast Asian branch of Al-Qaeda, which was responsible for the 2002 Bali bombings, Indonesia's worst-ever terrorist attack.

Other than that, WSJ reported on 8 May 2013 that Indonesian police had killed three suspected terrorists who were believed to be part of a group that plotted to bomb the Myanmar embassy in Jakarta. WSJ stated:

Antiterrorism police on Wednesday killed three suspected terrorists and arrested a fourth believed to be part of a group that plotted to bomb the Myanmar Embassy in Jakarta last week, the latest reverberations of a sectarian conflict in Myanmar that has galvanized radical Muslims in Indonesia (WSJ, May 8, 2013: Line 13)

Malaysia was also reported to be having issues relating to terrorism. WSJ on 28 October 2012 reported that two Malaysians were also involved:

Malaysia said Sunday that Lebanese authorities arrested two Malaysian citizens in Beirut on suspicion of having links with the al Qaeda terrorist organization. Malaysia's foreign ministry said the suspects were brought to the Military Court in Beirut and unspecified charges were read against them Thursday. Lebanese authorities were continuing to investigate the case and the two men were to appear in court again Monday, the ministry said (WSJ, October 28, 2012: Line 15)

Based on the above news excerpt, the researchers found that Malaysians have also involved in terrorism even though the location was not in Malaysia. For this issue, two Malaysians namely; Rafik Mohammed and Mohammed Razin Shaaban was found guilty as act as a team with al-Qaeda in Lubnan. Earlier, the involvement of Malaysian Muslims with terrorism activities was reported in a Malaysian newspaper, The Star, on 31 January 2016 which stated that the government of Malaysia was worried about the continuous numbers of Malaysians travelling to Syria to join the "Islamic State" (IS). Therefore, the Malaysian government has taken stern action by monitoring their family members and also sought a new strategy and new laws to tackle these threats.

\section{DISCUSSION AND CONCLUSION}

It was found that WSJ has much more coverage when it comes to reporting on issues related to Islam and Muslims in Malaysia and Indonesia. This outcome shows that the US media pay attention to reporting the news about Islam and Muslims in Malaysia and Indonesia. This is in line with the literature cited previously in this study which proved by Ali (2008) that the US print media reported the issues of political turmoil, unrest, law and order, inflation, deficit and economic conditions, especially in Indonesia, which led to a negative impression of the country. However, issues such as religious extremist, fundamentalist, holy man, Muslim rebels and Muslim extremist were linked with Muslims in Malaysia. This indicates that the US print media is consistent in reporting on issues in Malaysia and Indonesia until now. To compare between Malaysia and Indonesia coverage of Islam and terrorism issues, this articles found out that the abundance of issues pertaining to religious matters about Muslims in Indonesia is in line with Desker (2002) who states that the government of Indonesia give strong attention to the 
religious needs of the Muslim community even though it does not transform Indonesia into an Islamic state. In addition, Dafrizal et al. (2013) outlined the history of terrorism incidents in Indonesia and how it has led to the greatest coverage of that particular issue. Therefore, the findings of Dafrizal et al. are in line with the present finding that Indonesia received more coverage from WSJ than Malaysia especially on issues related to terrorism.

The coverage of terrorism mostly in Indonesia and Malaysia in this newspaper is not surprising. This is because the issues reported, such as about the Al-Qaeda organization and suspected terrorists in Indonesia, have become a common topic in the media everywhere. However, the involvement of Malaysian Muslims going to join "jihad" in Syria and Iraq seems to pose a new threat to the Malaysian government. The researchers believed that Indonesia faces morechallengesinfacing security threats than Malaysia due to the existence of an extremist "jihad" legacy for a long time in Indonesia such as JI. This is in line with the literature which reports that the number of Malaysians who have joined the terrorist groups are still small as compared with Indonesia. The findings of the study indicated that the news coverage on terrorism contributed to the effect of media framing. By highlighting the frames of terrorist or terrorism it shows that the major attention was paid by the journalist to emphasizing terrorist or terrorism frames to the audiences.

\section{REFERENCES}

Ahmad, F. (2006). British Muslim perceptions and opinions on news coverage of September 11. Journal of Ethnic and MigrationStudies, 32(6), 961-982.http:// dx.doi.org/10.1080/13691830600761479.

Ali, S. (2008). US print media and portrayal of Muslim world: A study of Newsweek and Time (1991-2000) (Ph.D Dissertations, Bahauddin Zakariya University, Multan).

Allen, F. (2014). Islamophobia in the UK: The role of British newspapers in shaping attitudes towards Islam and Muslims. Retrieved from http://repository. uwtsd.ac.uk/413/1/Fleur\%2oAllen $\% 20$ new.pdf.

Alshammari, D. (2013). Islamophobia. International Journal of Humanities and Social Science, 3(15), 177-18o.

Asia Muslim Population. (2014). Retrieved from http://www.muslimpopulation. com/asia/.

Cassidy, R.M. (2008). Terrorism and insurgency. Parameters. 38, 129-140.

Creswell, J.W. (2012). Educational Research: Planning, Conducting and Evaluating Quantitative and Qualitative Research. Boston, MA: Pearson.

Dafrizal, Faridah Ibrahim, Chang Peng Kee \& Fauziah Ahmad. (2013). Trend pemberitaan isu keganasan dalam akhbar perdana Malaysia dan Indonesia. Malaysian Journal of Communication, 29(2), 189-202.

Dafrizal Samsudin \& Faridah Ibrahim (2010). Framing of 'terrorism' issues in Indonesia: A study of two Malaysian and Indonesian mainstream newspapers. Journal of Media and Information Warfare, 3,15-35. 
Desker, B. (2002). Islam and society in South-East Asia after 11 September. Australian Journal of International Affairs, 56(3), 383-394, doi: 10.1080/1035771022000019714

Entman R. (1993). Framing: Toward clarification of a fractured paradigm. Journal of Communication, 43(4), 51-58. doi: 10.1111/j.1460-2466.1993.tbo1304.X

Eliraz, G. (2004). Islam in Indonesia. Brighton: Sussex Academic Press.

Fauziah Hassan. (2017). News coverage on Islam and Muslims in Malaysia and Indonesia by Wall Street Journal and The Telegraph. (Ph.D Thesis, Universiti Putra Malaysia, Malaysia).

Faridah Ibrahim. (2008). Media Stereotyping: Reporting war and terorism. Journal Online, South-South Information Gateway (SSIG).

Faridah Ibrahim. (2003). Pengaruh pengurusan akhbar ke atas bilik berita. Dlm. Samsudin A. Rahim (pnyt). Kumpulan esei: Isu-isu komunikasi, hlm. 267-284. Bangi: Pusat Pengajian Media dan Komunikasi, Universiti Kebangsaan Malaysia.

Fealy, G., \& Hooker, V. (2006). Voices of Islam in Southeast Asia: A Contemporary Sourcebook. Institute of Southeast Asian Studies (ISEAS), Singapore.

Fealy, G., Hooker, V., \& White, S. (2006). Indonesia. In Fealy, G., \& Hooker, V. (Eds), Voices of Islam in Southeast Asia. Pasir Panjang, Singapore: Institute of Southeast Asian Studies (ISEAS).

Funk, N. C., \& Abdul Aziz, S. (2004). Islam and the west: Narratives of conflict and conflict transformation. International Journal of Peace Studies, 9 (1), 1-28. Retrieved from http://www.gmu. edu/programs/icar/ijps /vol9_1/ Funk\&Said_91IJPS.pdf.

Ghoshal, B. (2010). Arabization: The changing face of Islam in Asia. India Quarterly, 66(1), 69-89. doi: 10.1177/097492841006600105.
Hashim, F. Y. (2009). Islam dan terrorisme. Pemikir. 55, 49 - 66.

Hefner, R. W., \& Horvatich, P. (1997). Islam in an era of Nation-States: Politics and Religious Renewal in Muslim Southeast Asia. USA: University of Hawai'i Press.

Houben, V. J. H. (2003). Southeast Asia and Islam. The ANNALS of the American Academy of Political and Social Science, 588(2003), 149-170, doi: 10.1177/0002716203588001010.

Isma Adila. (2011). Media dan Pemberitaan Terrorisme (Analisis Framing Pemberitaan Terrorisme di Indonesia pada Surat Kabar Kompas Edisi Tahun 2010. Retrieved from http:// etd.repository.ugm.ac.id/index. php?mod=penelitian_detail\&sub=Pen elitianDetail\&act $=$ view \&typ $=$ html\&bu $\mathrm{ku} \_\mathrm{id}=52813$.

Isyaku Hassan, Mohd N. L. Azmi \& Usman I. Abubakar. (2017). Framing Islam in News Reporting: A Comparative Content Analysis. Asian Social Science, 13(10), 112-119.

JiYoung Cho \& Eun-Hee Lee. (2014). Reducing confusion about grounded theory and qualitative content analysis: Similarities and differences. The Qualitative Report, 19(64), 1-20. Retrieved from http:// nsuworks.nova.edu/tqr/volig/iss32/2/.

Kabir, N.S \& Bourk, M. (2012). Representing Islam and Muslims in New Zealand newspapers. Journal of Muslim Minority Affairs, 32(3), 324-338. doi:10.1080/1360 2004.2012.727293

Kumala Citra Somara Sinaga. (2016). Analisis Framing Pemberitaan Bom Sarinah Di Kompas.Com Dan Merdeka.Com. JOM FISIP, 3(2), 1-12.

Laqueur, W. (2002). A history of terrorism. New Jersey: Transaction Publishers.

Mahony, I. (2010). Diverging frames: A comparison of Indonesian and Australian press portrayals of terrorism and Islamic groups in Indonesia. International Communication 
Fauziah Hassan, Sofia Hayati Yusoff, dan Siti Zobidah Omar, An Initial Exploration on Terrorism Issues in Malaysia ...

Gazette, $\quad 72(8), \quad 739-758 . \quad$ doi: $10.1177 / 1748048510380813$

Mc Quail, D. (1995) Media performance: Mass communication and the public interest. London: Sage.

Merriam, S. B. (2009). Qualitative research: A guide to design and implementation. San Francisco, CA: John Wiley and Sons, Inc.

Miller, E., \& Daily, E. (2013). Understanding and measuring outcomes: the role of qualitative data. Institute for Research and Innovation in Social Services.

Neuman, W. L. (2014). Social research methods: Qualitative and quantitative approaches. USA: Pearson.

Neuman, L. W. (1997) Social research methods: Qualitative and quantitative approaches. Boston: Allyn \& Bacon.

Noor Mayudia, M.M., Siti Hajar, A.A., \& Shahril Anuar, A.G. (2010) The framing of Islamic-related world news by international news agencies in Malaysia in an English mainstream newspaper, The Star. In Mazni, B., Nur Kareelawati, A.K., Sofia Hayati, Y. \& Suria Hani A.R (eds). Portrayal of Islam in the Media. Nilai: USIM.

Perreault, G. (2014). "Islam is everywhere": Pre-Arab spring coverage of Islam in the

English Egyptian press. Journal of Media and Religion, 13(2), 97-113. doi: 10.1080/15348423.2014.909207

Poole, E. \& J.E. Richardson. (2006). Muslims and the news media. London: I. B Tauris.

Population Reference Bureau. (2014). Retrieved October 7, 2014, from www. prb.org.

Rane, H., \& Ewart, M. (2012). the framing of Islam and Muslims in the tenth anniversary coverage of 9/11: implications for reconciliation and moving on. Journal of Muslim Minority Affairs, 32(3), 310-322. doi: $10.108 \mathrm{o} / 13602004.2012 .727292$.
Macnamara, J. (2011). Media content analysis: its uses, benefits and best practice methodology. Asia Pacific Public Relations Journal, 6(1), 1-34. Retrieved from http://amecorg.com/wp-content/ uploads/2011/10/Media-ContentAnalysis-Paper.pdf.

Muhammad Raqib Mohd Sofian \& Adnan Hussein. (2013). Media coverage on religious conflict in Malaysia: a preliminary study on how the star and Utusan Malaysia framed the attempts to subvert the faith and believe of Muslims in a multiracial thanksgiving dinner at DUMC. Procedia Social and Behavioral Sciences, 91(2013), 461-474. Doi: 10.1016/j.sbspro.2013.08.444

Nelson, S. A. D. (2006). News reporting on terrorism in Malaysia and Singapore. Media Asia, 33(3), 192-200.

Nelson, S. A. D. (2004). Southeast Asian press coverage of terrorism and the Bali bombing. The Copenhogen Journal of Asian Studies 20, 47-69.

Neuman, L.W. (2006). Social research methods: Qualitative and quantitative approaches. Boston: Pearson.

Patton, M. Q. (2001). Qualitative research and evaluation methods (2nd Edition). Thousand oaks, CA: Sage Publications.

Ridzuan Wu. (1990). The call to Islam: A contemporary perspective. Muslim Converts' Association of Singapore.

Rose, S., Spinks, N., \& Canhoto, A. I. (2015). Management research: Applying the principles ( $\left.1^{\text {st }} \mathrm{Ed}\right)$. United Kingdom: Routledge.

Saodah Abd Rahman (2017, February 3). Fahami isu sensitif berkaitan agama. Utusan Online.

Retrieved from http://www.utusan.com.my/ rencana/fahami-isu-sensitif-berkaitanagama-1.439691

Seale, C., \& Tonkiss, F. (2012). Content and comparative keywords analysis. In Seale, C. Researching society and culture 
( $\left.3^{\text {rd }} \mathrm{Ed}\right)$. Los Angeles: Sage Publication.

Severin, W. J. \& Tankard, J. W (2001). Communication theories: Origin, methods, and uses in the mass media ( $5^{\text {th }}$ edition). New York: Longman.

Shafizan Mohammad, Mazni Buyong \& Zeti Azreen (2014). From terrorist to Jihadist: A new portrayal of Muslims and Islam. Paper presented at Seminar Media and Da'wah, Universiti Sains Islam Malaysia (USIM).

Toeti Kakiailatu. (2007). Media in Indonesia: Forum for political change and critical assessment. Asia Pacific Viewpoint. 48(1), 60-71.

Wicaksono, Sigit (2017) Analisis bingkai pemberitaan tentang peristiwa bom Thamrin di Majalah Tempo dan Gatra. (Undergraduate thesis, Widya Mandala Catholic University Surabaya, Indonesia).

Wimmer, R.D. \& Dominick, J.R. (2011). Mass media research: An introduction. Wadsworth, USA: Cengage Learning.
Zaharom Nain (2002). The structure of the media industry: Implications for democracy, in F. Loh \& B. T Khoo (eds) Democracy in Malaysia: Discourses and practices, Richmond: Curzon.

Newspapers:

Utusan Malaysia, July, 25, 2009

Jakarta Post, July 31, 2009.

Wall Street Journal, August, 7, 2013

Wall Street Journal, October, 28, 2012,

Wall Street Journal, June, 6, 2013

Wall Street Journal, December, 9, 2013

Wall Street Journal, July, 22, 2013

Wall Street Journal, May, 8, 2013

Wall Street Journal, October, 28, 2012 